\title{
ANALISIS POTENSI DAN PENGEMBANGAN PARIWISATA BERBASIS MASYARAKAT DI DESA TULAKADI KAWASAN PERBATASAN INDONESIA
}

Yudha Eka Nugraha

Politeknik Negeri Kupang, Kupang, Indonesia, yudhaekanugraha@gmail.com

\section{Histori Artikel}

Submitted:

27 Juli 2020

Reviewed:

1 Okober 2020

Accepted:

12 Oktober 2020

Published:

15 November 2020

\section{ABSTRAK}

Penelitian ini bertujuan untuk mengidentifikasi potensi daya tarik wisata alam, budaya, maupun buatan di kawasan perbatasan Desa Tulakadi, Nusa Tenggara Timur. Tujuan lain yang ingin dicapai dalam penelitian ini adalah menentukan karakteristik dan pengembangan pariwisata berbasis masyarakat model Desa Tulakadi berdasarkan pendekatan komunitas. Metode dalam penelitian ini menggunakan jenis kualitatif deskriptif untuk analisis, eksplorasi potensi wisata dan pengembangan pariwisata berbasis masyarakat sesuai karakteristik masyarkat. Teknik pengumpulan data dilakukan melalui wawancara terstruktur danfocus group discussionbersama warga dan aparatur desa. Hasil dari penelitian ini adalah Desa Tulakadi memiliki berbagai potensi wisata perbatasan terutama budaya yakni pertunjukkan tarian likurai, pembuatan tenun ikat dengan pewarnaan alami, alam yakni bentang pemandangan sawah, laut dan pulau Alor, dan buatan yakni daya tarik PLBN Mota'ain dan destinasi asam Jokowi. Berdasarkan karakteristik masyarakat setempat dan pengembangan pendekatan pariwisata berbasis masyarakat, upaya yang dilakukan yakni melalui keterlibatan stakeholder seperti pemerintah, akademisi melalui sosialisasi dan pelatihan sadar wisata bagi masyarakat, dan pembentukan kelompok komunitas termasuk kelompok sadar wisata untuk mengembangkan kepariwisataan di Desa Tulakadi.

Kata Kunci: Perbatasan, Analisis Potensi, Nusa Tenggara Timur

\section{ATTRACTION ANALYSIS AND COMMUNITY BASED TOURISM APPROACH FOR TOURISMDEVELOPMENT IN RURAL AREA TULAKADI, INDONESIAN BORDER REGION}

\begin{abstract}
This study aims to identify potential natural, cultural, and artificial tourist attractions in the border area of Tulakadi Rural area, East Nusa Tenggara. Another objective to be achieved in this research is to determine and develop community-based tourism, Tulakadi Village based on a community approach. The method in this research uses descriptive qualitative types for analysis, exploration of tourism potential and tourism development according to community needs. The data technique was carried out through structured interviews and focus group discussions with residents and village officials. The results of this study show that Tulakadi Village has various tourism destination in border area, especially culture based such as likurai dances, weaving woven with natural coloring, natural landscapes of Alor Island, and artificial attraction, namely PLBN Mota'ain and Man Made attraction of Asam Jokowi site. Based on the community and the development of a community-based tourism approach, efforts are made through the interaction of stakeholders such as the government, academics through socialization and training for awareness of tourism for the community, and orders from community groups including tourism awareness groups to develop tourism in Tulakadi Village.
\end{abstract}

Keywords: Border Area, Potential Analysis, East Nusa Tenggara

\section{https://amptajurnal.ac.id/index.php/MWS}

Doi: $10.36275 / \mathrm{mws}$ 


\section{PENDAHULUAN}

Sebagai salah satu pendekatan yang sejalan dengan pembangunan pariwisata Indonesia, pariwisata berbasis masyarakat mulai digalakkan di berbagai kawasan di Indonesia. Sharley, 2000 menyatakan bahwa pendekatan berbasis masyarakat merupakan arah pembangunan pariwisata kerakyatan yang sesuai untuk wilayah perdesaan. Kebijakan pembangunan kepariwisataan terutama di kawasan perdesaan berfokus pada identifikasi, pengelolaan, dan pemanfaatan sumber daya pariwisata dalam rangka meningkatkan kesejahteraan masyarakat setempat. Bentuk pendekatan pariwisata yang berbasis masyarakat dalam masyarakat di kawasan perbatasan. Republik Indonesia sebagai sebuah negara memiliki 79 Pos Lintas Batas yang terbagi atas 47 pos berada di darat dan 32 pos berada di laut (Maulana 2019). Tidak banyak data yang menunjukkan data perlintasan antara orang yang masuk dan keluar melalui pintu tersebut, mengenai pos lintas batas Indonesia dan negara tetangga (Maulana 2019). Namun, salah satu Pos Lintas Batas yang cukup besar seperti salah satunya PLBN Mota'ain di Kabupaten Belu. Kepala Bidang Pemasaran Regional III Kemenpar menyebutkan bahwa sepanjang Januari - Oktober 2018 PLBN Mota'ain mencapai 41.436 wisatawan. Data lain menunjukkan bahwa sepanjang Januari-Juli 2018, jumlah wisatawan mancanegara berjumlah 986.358 dimana Belu menjadi penyumbang wisman terbanyak dengan jumlah 509.295 atau setara dengan total arus masuk wisman ke Nusa Tenggara Timur. Data BPS menunjukkan, wisman yang berasal dari Timor Leste pada periode Januari hingga Juli 2018 berjumlah 1.005 .600 orang. Jumlah ini diklaim naik $89,16 \%$ sebanyak 531.600 dibandingkan periode yang sama pada tahun sebelumnya.

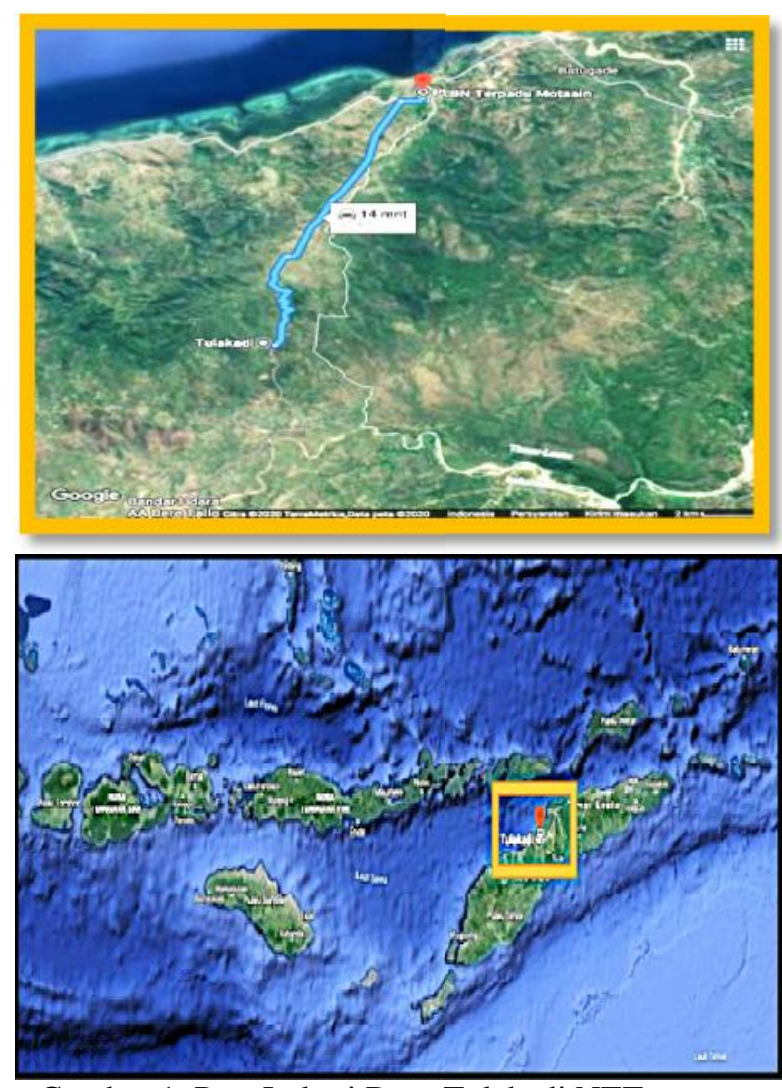

Gambar 1. Peta Lokasi Desa Tulakadi NTT, sumber: google maps

Pemerintah RI melalui Kementerian Pariwisata telah memberikan berbagai stimulus untuk meningkatkan kunjungan ke kawasan perbatasan Indonesia, seperti event yang dilakukan KonserMusik Cross Border di Atambua (2018 dan 2019), Festival Fulan Fehan (2018).

Berdasarkan laporan Kemenpar, 2019, jumlah kunjungan wisatawan untuk kegiatan Konser Musik Cross Border di Atambua berjumlah 1.852 orang dalam waktu dua hari. Selain itu, pembangunan PLBN Mota'ain merupakan salah satu unsur penunjang pariwisata dalam akses perjalanan. Pembangunan yang semakin baik di kawasan perbatasan membuat masalah aksesibilitas bukan menjadi penghalang bagi wisatawan untuk melakukan kegiatan wisata di kawasan perbatasan Kabupaten Belu. Namun, keberadaan wisatawan ini tidak berlangsung lama. Setelah selesai menghadiri event yang diselenggarakan pemerintah, wisatawan kembali ke negara asalnya Timor Leste. Keterbatasan amenitas, atraksi wisata lain, dan dukungan dari aciliary masih menjadi 
permasalahan yang dihadapi oleh pariwisata kawasan perbatasan.

Sebenarnya, terdapat berbagai wilayah di kawasan perbatasan yang memiliki sumber daya baik alam maupun budaya yang dapat dimanfaatkan untuk pengembangan pariwisata yang pada ujungnya membawa dampak positif bagi masyarakat sekitar (Nugraha, 2019). Salah satunya adalah di desa Tulakadi yang berada tidak jauh dari PLBN Mota'ain. Berdasarkan citra satelit yang diperoleh dari website google maps, Jarak antara PLBN Mota'ain dan Desa Tulakadi tidak terlalu jauh, yaitu sepanjang 9 km. Sebelum memasuki Kota Atambua, wisatawan yang lewat dari PLBN Mota'ain pasti akan melewati jalan negara mulai dari Desa Silawan, kemudian Desa Tulakadi. Melihat pasar wisatawan yang potensial, maka pemetaan potensi daya tarik wisata dibutuhkan sebagai upaya mempersiapkan Desa Tulakadi menjadi salah satu destinasi wisata yang menarik di kawasan perbatasan Indonesia.

Potensi pariwisata di kawasan perbatasan sejauh ini belum dipetakan secara optimal. Hal ini terlihat dari belum adanya usaha untuk meninjau daya dan ketidaktahuan mengenai kepariwisataan itu sendiri. Satusatunya dukungan yang didapatkan masyarakat setempat untuk mengelola kepariwisataan hanya berasal dari Kepala Desa Tulakadi yang senantiasa membantu dalam memotivasi masyarakat. Hanya, keterbatasan dalam pengelolaan juga menjadi hambatan bagi pemerintah desa untuk maksimal memberikan pengetahuan bagi masyarakat. Mengatasi hal ini, pihak akademisi dari jurusan pariwisata beberapa kali memberikan sosialisasi dan pelatihan bagi warga masyarakat. Kegiatan ini merupakan cikal bakal terbentuknya kelompok sadar wisata Desa Tulakadi. Pemetaan potensi pariwisata tersebut dilakukan melalui analisis potensi mulai dari sumber daya alam, sumber daya budaya, dan sumber daya buatan yang ada di Desa Tulakadi, dan kegiatan ini masih dalam proses untuk dipetakan bekerjasama dengan akademisi.
Desa Tulakadi pada faktanya memiliki daya tarik yang membuat wisatawan berkunjung. Hal ini dibuktikan dengan kunjungan warga yang berulang untuk sekedar berekreasi (Susuk, 2019)diatas bukit asam Jokowi dan berfoto Bersama di areal Desa Tulakadi. Peluang ini ada, walaupun potensi daya tarik wisata Desa belum sepenuhnya dikelola, sehingga pemetaan potensi wisata adalah salah satu usaha desa yang dapat dilakukan untuk mengelola kawasan wisata dengan lebih baik. Keberagaman sumber daya alam, budaya, dan buatan Desa Tulakadi yang dipetakan secara lebih baik merupakan perwujudan dari produk pariwisata potensial yang dapat dikembangkan menjadi sebuah daya tarik kawasan perbatasan Indonesia.

Masyarakat setempat sebagai tuan rumah kawasan perbatasan di Desa Tulakadi, memiliki kesempatan untuk mengelola tanahnya sebagai sumber penghasilan dari kegiatan pariwisata. Namun, hal ini tidak dapat terjadi secara instan. Diperlukan berbagai upaya pengembangan yang berbasis pada kesediaan masyarakat untuk mengelola kawasannya menjadi destinasi pariwisata yang terpadu. Berdasarkan hal ini, dibutuhkan berbagai pendekatan yang harus dilakukan untuk membangun kesiapan sumber daya manusia di Desa Tulakadi. Sejauh ini, dukungan sudah diperoleh dari pemerintah pusat dan pemerintah daerah. Pihak akademisi dan media juga telah memberikan partisipasinya untuk mengelola pengembangan pariwisata di kawasan perbatasan. Satu yang perlu ditingkatkan adalah pengelolaan yang berbasis masyarakat. Strategi ini menurut literature merupakan pendekatan yang paling cocok dalam pengembangan kawasan perbatasan adalah pengembangan pariwisata yang berbasis masyarakat (Ernawati, 2015). Karakterisitik masyarakat NTT yang senang bekerjasama dan berkelompok merupakan modal yang kuat untuk melakukan pendekatan pariwisata berbasis masyarakat.

Berdasarkan latar belakang tersebut, maka penelitian ini berfokus pada upaya awal untuk memetakan dan menganalisis, daya tarik Desa Tulakadi di kawasan perbatasan. 
Kemudian setelah mendapatkan identifikasi potensi daya tarik wisata. Hasil identifikasi tersebut dikembangkan sesuai dengan karakteristik sumber daya manusia di Desa Tulakadi. Tujuan ketiga dalam penelitian ini adalah mengidentifikasi pengembangan pariwisata berbasis masyarakat sesuai dengan potensi wisata dan karakteristik yang dimiliki oleh Desa Tulakadi sebagai kekuatan untuk mengembangkan pariwisata berbasis masyarakat di kawasan perbatasan Indonesia.

\section{LITERATUR REVIEW}

\section{Potensi Daya Tarik Wisata}

Kajian mengenai potensi daya tarik wisata sudah dilakukan sejak tahun 1983 dimana (Yoeti 1983:160-162) menyebutkan bahwa potensi adalah daya tarik di sebuah destinasi wisata yang menjadi penarik agar wisatawan mau datang ke tempat tersebut. (Sukardi,1998) juga menyampaikan hal yang senada mengenai potensi wisata, dimana menurutnya segala sumber daya yang dimiliki oleh daya tarik wisata dalam sebuah kawasan. Sehingga, dalam penelitian ini potensi wisata dibagi menjadi tiga macam mengacu pada teori Yoeti, yaitu: potensi alam, potensi kebudayaan dan potensi manusia.

Potensi alam adalah daya tarik wisata yang berupa keanekaragaman hayati, bentang alam suatu kawasan wisata misalnya perbukitan persawahan, hutan, dan pantai. Keanekaragaman hayati dan hewani pada suatu wilayah geografis tentu berbeda satu sama lainnya dan memiliki kelebihan dan keunikannya sendiri. Sehingga potensi alam kerap kali menjadi salah satu faktor yang menarik wisatawan berkunjung.

Potensi Budaya adalah seluruh hasil karya karsa dan daya cipta masyarakat setempat yang diwariskan secara turun temurun sejak nenek moyang berupa kain adat, adat istiadat, norma, kerajinan tangan, kesenian lukis dan tari, dan seluruh peninggalan pendahulu yang berupa benda berwujud maupun tak berwujud seperti Gedung bersejarah, monument, patung, dan dokumen-dokumen sejarah.

Potensi manusia dan wisata buatan adalah potensi yang menjadi daya tarik lain dalam suatu kawasan destinasi wisata. Bentuk wisata manusia dan buatan tergantung pada karakteristik wilayah dan adat istiadat. Namun, wisata buatan juga tergantung kepada inovasi, prakarsa, dan kreatifitas warga setempat dalam mengembangkan destinasinya menjadi sebuah daya tarik wisata.

Potensi wisata adalah segala sesuatu yang terdapat di suatu daerah yang dapat dikembangkan menjadi daya tarik wisata atau segala hal keadaan yang nyata atau dapat diraba, maupun yang tidak dapat diraba, yang digarap diatur dan sedemikian rupa sehingga dapat di manfaatkan atau diwujudkan (Darmardjati, 2001). Jadi potensi yang dimaksud dalam penelitian ini adalah segala sumber daya baik alam, budaya, maupun buatan yang ada di Desa Tulakadi yang dapat dikelola dan dikembangkan sebagai daya tarik wisata di kawasan perbatasan.

\section{Pariwisata Berbasis Masyarakat}

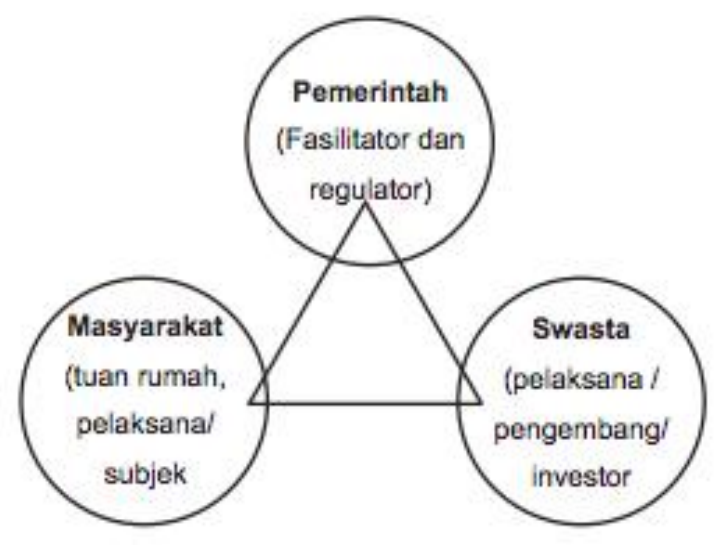


Pariwisata berbasis masyarakat merupakan pendekatan kepariwisataan yang mengutamakan adanya peran dan partisipasi masyarakat dalam membangun kegiatan pariwisata di suatu kawasan atau daerah. Senada dengan hal ini beberapa peneliti sebelumnya juga menyatakan bahwa pariwisata berbasis masyarakat sangat mengutamakan masyarakat dalam perencanaan, pengembangan, pengelolaan, dan kepemilikannya (Hausler and Strasdas, 2003; Asker et.al. 2010; UNWTO, 2011; Tasci.et. al. 2013; Nugraha, 2020). Terdapat beberapa karakteristik lain yang juga menunjukkan bahwa sebuah destinasi dikelola dengan menggunakan pendekatan pariwisata berbasis masyarakat yakni: cakupan berskala kecil, terdapat unsur edukasi dan interpretasi dalam seluruh produknya, mempromosikan berbagai nilai penting seperti konservasi terhadap lingkungan, sosial, dan budaya (Hausler and Strasdas, 2003).Pada kajian lain mengenai pariwisata berbasis masyarakat, pendekatan ini memberikan peluang yang besar kepada masyarakat. Porsi partisipasi masyarakat yang besar dalam hal partisipasi dan melakukan pembangunan untuk wilayahnya sendiri membuat pengembangan wilayah lebih mudah dilaksanakan jika dikerjakan sesuai dengan kaidah yang baik (Dewi, 2013 dalam Sunarjaya 2019).Masyarakat lokal berperan sebagai tuan rumah dan menjadi pelaku penting dalam pengembangan desa wisata dalam keseluruhan tahapan mulai tahap perencanaan, pengawasan, dan implementasi. Ilustrasi yang dikemukakan Wearing (2001) tersebut menegaskan bahwa masyarakat lokal berkedudukan sama penting dengan pemerintah dan swasta sebagai salah satu pemangku kepentingan dalam pengembangan pariwisata.

Strategi pelaksanaan partisipasi dalam pariwisata berbasis masyarakat dicapai dengan cara melibatkan masyarakat dalam sharing informasi, merumuskan tujuan, menentukan kebijakan, mengalokasikan sumber-sumber pendanaan, mengoperasikan program, serta mendistribusikan manfaat yang diperoleh. Masyarakat dilibatkan sejak tahap perencanaan hingga implementasi dan pemerataan hasilhasilnya. Selain dengan partisipasi, ahli menyebutkan bahwa kunci pembangunan pariwisata berbasis Community-Based Tourism, meliputi beberapa hal, yaitu: (1) Adanya dukungan pemerintah; (2) Partisipasi dari stakeholder; (3) Pembagian keuntungan yang adil; (4) Penggunaan sumber daya lokal secara berkesinambungan; (5) Penguatan institusi lokal; (6) Keterkaitan antara level regional dan nasional (Pantiyasa, 2011).

\section{METODE}

Metode yang digunakan dalam penelitian ini yakni analisis deskriptif kualitatif (Sugiyono, 2015). Data yang digunakan terdapat dua jenis data kualitatif yakni hasil dari wawancara dan FGD yang diaplikasikan secara berkelompok untuk meningkatkan hasil penelitian (O. Nyumba, 2018)Bersama apparat desa dan masyarakat. Data kuantitatif adalah data yang bersumber dari data sekunder mengenai jumlah penduduk, tingkat pendidika masyarakat, umur, dan jumlah kunjungan wisatawan potensial yang sejauh ini berkunjung di seputar kawasan perbatasan. Pengumpulan data menggunakan pendekatan data primer yakni observasi dan wawancara serta FGD, sedangkan data sekunder dikumpulkan melalui buku-buku pariwisata berbasis masyarakat yang relevan. Sebanyak 5 informan menjadi informan kunci dalam penelitian yang dipilih dengan menggunakan purposive sampling yaitu Kepala Desa, Kepala Pokdarwis, Pengelola DTW, Masyarakat, dan Wisatawan. Teknik analisis data menggunakan analisis deskriptif kualitatif

\section{HASIL DAN PEMBAHASAN}

\section{Potensi Daya Tarik Wisata di Desa Tulakadi}

Potensi Daya Tarik Wisata Desa Tulakadi Berbasis Alam

Daya tarik alam merupakan salah satu potensi wisata yang memperkuat daya tarik bagi wisatawan. Potensi wisata berbasis alam dapat berbentuk hutan, pegunungan, bukit, dan bahkan pantai. Indonesia yang 
merupakan negara kepulauan secara geografis telah menjamin bahwa segala bentuk kekayaan alam dapat dinikmati dan dijadikan daya tarik. Seperti yang ada di kawasan perbatasan Desa Tulakadi. Kawasan ini merupakan kawasan potensial yang setiap harinya dilewati oleh wisatawan dari negara tetangga (Timor Leste). Negara yang memiliki kedekatan secara geografis ini menyumbang wisatawan terbanyak kedua setelah Kepulauan Riau (Data BPS 2018) yang berarti bahwa selain dari segi geografis, wisatawan juga memiliki ketertarikan untuk menjelajah dan melakukan perjalanan di kawasan perbatasan Indonesia. Hal ini terkait pula dengan latar belakang budaya Indonesia dan masyarakat Timor Leste yang hampir sama, sehingga dalam beberapa kasus, wisatawan yang datang adalah juga kerabat dari masyarakat setempat. Kekayaan alam di Desa Tulakadi dapat ditemukan dalam bentuk areal perbukitan dan juga persawahan. Areal perbukitan dapat ditemukan mulai dari pintu masuk menuju daya tarik wisata Asam Jokowi (tempat bersejarah dimana Jokowi memberikan bantuan dana kepada masyarakat setempat untuk dikelola). Dibelakang tempat bersejarah ini. Pemandangan laut di depan mata dapat diamati dari atas bukit. Pemandangan ini merupakan sebuah atraksi alam yang menjadi daya tarik bagi wisatawan yang berkunjung ke lokasi ini. Kerap kali ditemukan wisatawan yang menghabiskan waktu senggang dengan

duduk di sekitar bukit. Bahkan sekarang saat kursi-kursi dipasang untuk meningkatkan kenyamanan wisatawan, jumlah pengunjung semakin banyak. Namun, peningkatan kunjungan wisatawan ini masih belum dikelola dengan baik oleh masyarakat setempat sehingga pencatatan jumlah kunjungan belum tersedia.

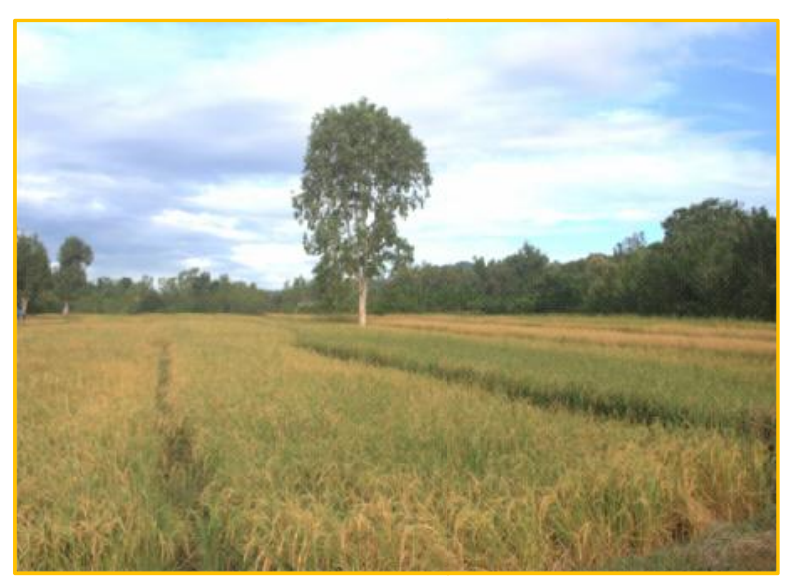

Gambar 3. Perbukitan dan pematang sawah, sumber: dokumentasi pribadi, 2020

Selain potensi alam berupa perbukitan yang memiliki pemandangan lautan, tempat ini juga memiliki kekayaan alam lain berupa batu alam, dan lokasi persawahan yang membentang di sepanjang jalan dari Desa Tulakadi menuju PLBN Mota'ain. Tempat ini sangat bersih dan hampir tidak ditemukan sampah di sepanjang perjalanan. Masyarakat selalu membersihkannya ketika melihat sampah yang berserakan. Kehidupan masyarakat yang sederhana membuat konsumsi rumah tangga masyarakat setempat bertumpu pada tanaman-tanaman pangan yang mudah ditemukan sehari-hari. Persawahan yang membentang selalu dapat ditanami padi dan sepanjang tahun akan menghasilkan padi. Selain padi, komoditas lain yang dibudidayakan di Desa Tulakadi adalah jagung. Potensi alam persawahan dapat dinikmati oleh wisatawan secara gratis, terdapat di sebelah kanan dan kiri jalan lintas negara dari Desa Tulakadi menuju PLBN Motaain. Sedangkan untuk menaiki perbukitan, terdapat tiket masuk yang menjadi kontribusi wisatawan untuk mendukung kegiatan pariwisata di Desa Tulakadi, biaya untuk satu orang pengunjung adalah 3.000 rupiah.

\section{Potensi Daya Tarik Wisata Desa Tulakadi Berbasis Budaya}

Provinsi Nusa Tenggara Timur pada umumnya dan Desa Tulakadi pada khususnya memiliki kesamaan budaya yang menjadi potensi daya tarik wisata. Provinsi ini dianugerahi kekayaan budaya yang 
berlimpah, sehingga tidak akan habis dijadikan sebuah magnet penarik bagi wisatawan. Desa Tulakadi misalnya, dari segi nama, pengambilan katanya dikenal memiliki makna purba yakni dari asal kata tula dan kadi. Tula berarti menyimpan atau penyimpanan dan kadi adalah batu asahan. Jika digabungkan, maka Tulakadi bemakna tempat penyimpanan batu asahan. Masyarakat setempat percaya bahwa asal kata ini merupakan budaya yang dihormati dan menjadi dasar bagi masyarakat untuk hidup bermasyarakat sehari-hari. Desa Tulakadi juga bermakna perdamaian karena batu asahan tersebut disimpan dengan baik. Disimpan artinya tidak digunakan lagi untuk menajamkan benda tajam yang biasa dipakai untuk berperang. Cerita itu selalu abadi dan diwariskan turun menurun.

Filosofi budaya Desa Tulakadi yang begitu kuat tidak hanya terlihat dari unsur penamaan Desa Tulakadi, tapi juga pada kekayaan budaya lainnya seperti Tarian Likurai yang merupakan tarian penyambutan dan penghormatan bagi tamu. Pada zaman dahulu, tarian ini dilakukan untuk menyambut mereka yang telah berjuang sehabis perang. Namun, saat ini, tarian ini dipercaya sebagai ungkapan syukur ketika panen raya tiba. Tarian Likurai sebenarnya merupakan tarian yang dikenal di seluruh wilayah Kabupaten Belu, namun banyak lokasi wisata yang menjadikannya sebagai pertunjukkan untuk menarik wisatawan datang berkunjung. Tarian ini dilakukan oleh laki-laki dan perempuan berjumlah sekitar 12 orang dalam sekali pertunjukkan tari. Tarian ini sangat dipertahankan keberadaannya karena merupakan salah satu pertunjukkan seni dan budaya yang memiliki daya tarik tersendiri.

Tidak lengkap rasanya apabila di suatu wilayah tidak memiliki identitas budaya yang terlihat dari sajian makanan tradisional. Sama halnya dengan Desa Tulakadi, makanan khas yang menjadi unggulan di kawasan perbatasan ini yakni olahan jagung bose. Masyarakat setempat mengonsumsi jagung bose sebagai pengganti nasi. Makanan ini terbuat dari jagung yang berkuah, dan biasanya disandingkan penyajiannya Bersama ikan. Sajian ini memiliki cita rasa yang unik, karena pada dasarnya jagung bose memiliki rasa yang tawar karena tidak ditambah bumbu lain. Adapun garam disajikan sebagai pelengkap sehingga penikmat bisa memilih untuk menggunakan garam atau tidak. Olahan Jagung Bose juga dilengkapi dengan sambal lu'at khas NTT yang memberikan cita rasa pedas dan segar saat mengonsumsi jagung bosen. Olahan makanan ini menyehatkan karena direbus secara sederhana dan disajikan tanpa menggunakan garam.

Potensi budaya lain yang menjadi daya tarik tersendiri adalah kerajinan anyaman yang berbahan dasar daun lontar. Anyaman ini membutuhkan sebuah proses yang tekun untuk membuatnya. Mulai dari proses pengumpulan bahan baku, memilih bahan baku yang layak digunakan, sampai akhirnya menjadi sebuah bentuk tersendiri berupa asbak, tempat permen, dan pajangan lainnya. Anyaman lontar ini merupakan sebuah kerajinan yang menggunakan unsur budaya terkait dengan kebiasaan warga setempat yang menggunakan daun lontar sebagai atap dari rumah adat yang sejak dahulu telah ada. Kearifan lokal inilah yang menjadi awal mula pemanfaatan daun lontar untuk mendukung kegiatan pariwisata sehingga dibentuk menjadi lebih menarik.

Selain daun lontar yang diubah menjadi anyaman, salah satu atraksi budaya lain yang dapat ditemukan di Desa Tulakadi adalah kain tenun yang menggunakan pewarna alami. Kain tenun khas Desa Tulakadi tidak menggunakan pewarna sintetis dikarenakan harganya yang mahal. Justru, mama-mama setempat yang membuat tenun ikat menggunakan pewarna alami dari bahan akar, dedaunan, dan bahan alami lainnya. Proses pembuatannya membutuhkan waktu seminggu hingga sebulan tergantung pada lebar kain yang dihasilkan. Bahan pewarna yang digunakan sangat ramah lingkungan, dibuat dari akar pepohonan sehingga kain tenun yang dihasilkan memiliki harum yang khas.

\section{Potensi Daya Tarik Wisata Desa Tulakadi Berbasis Buatan Manusia}


Selain potensi sumber daya alam dan buatan, potensi daya tarik lain adalah potensi buatan. Potensi daya tarik ini dikenal dengan sebutan man made. Daya tarik wisata buatan membutuhkan kreatifitas dan inovasi dari masyarakat setempat yang mengelola kawasannya menjadi sebuah daya tarik wisata untuk membuat wisatawan bertahan lebih lama di daya tarik tersebut. Desa Tulakadi memulai pengelolaan daya tarik wisata buatan saat lokasi ini didatangi oleh Presiden Jokowi.

Kunjungan tersebut bertujuan untuk meningkatkan motivasi masyarakat sekaligus pemerintah desa untuk segera mengelola daya tarik wisata berdasarkan potensi yang dimiliki oleh Desa Tulakadi. Kunjungan ini membawa efek yang kuat bagi pemerintah desa dan masyarakat. Hal ini ditandai dengan inisiasi pengelolaan bukit asam Jokowi yang sekarang dipenuhi dengan berbagai spot foto. Spot foto ini dibuat dengan mengumpulkan kayu-kayu bekas, dan bahan lain yang mudah ditemukan di alam. Belum adanya dukungan dari pihak lain membuat pemerintah desa secara swadaya Bersama masyarakat melakukan penataan daya tarik di bukit Asam Jokowi.Masyarakat setempat memiliki motivasi yang tinggi dalam melakukan penataan ini dan didominasi oleh masyarakat muda yang sehari-harinya bekerja sebagai buruh ataupun tidak bekerja. Upaya ini juga merupakan sebuah strategi dari pemerintah desa untuk menghindarkan anak-anak muda dari pengangguran. Sehingga semua pemuda yang tidak bekerja diperbantukan untuk mengelola daya tarik wisata Bukit Asam Jokowi.

Kawasan Bukit Asam Jokowi yang dikelola atas swadaya masyarakat memiliki areal yang luas. Terdapat beberapa spot foto yang cukup untuk menahan wisatawan berlama-lama di daya tarik ini. Angin yang sejuk, pemandangan lautan, dan perbukitan yang disuguhkan ketika sampai di Bukit Asam Jokowi membuat wisatawan banyak yang menikmati waktu santainya di tempat ini. Spot foto yang dibuat oleh masyarakat muda di kawasan ini beraneka ragam, mulai dari bentuk hati, bintang, tulisan-tulisan khas yang romantic, dan tempat duduk untuk bersantai. Banyak wisatawan yang senantiasa membawa perbekalannya sendiri ketika sedang berwisata. Hal ini mengingat belum adanya pelaku UMKM yang menjual berbagai kebutuhan pendamping. Adapun jaraknya cukup jauh dan harus menuruni bukit sehingga wisatawan memilih membawa perbekalannya sendiri.

Walaupun belum banyak aktivitas wisata yang dapat dilakukan, namun kerjasama warga desa dan keterbukaannya dalam menerima kepariwisataan merupakan tanda bahwa Desa Tulakadi mulai menerapkan sapta pesona dalam mendukung kepariwisataan di kawasan perbatasan. Daya tarik buatan ini semakin mengukuhkan bahwa masyarakat Desa Tulakadi memiliki kesiapan, namun saat ini terbatas pada permasalahan pendanaan dan pengelolaan yang membutuhkan biaya besar. Pengelolaan saat ini dilakukan secara swadaya, karena belum adanya investor yang mau memberikan bantuan. Padahal seluruh kawasan ini kepemilikannya adalah milik warga dan sangat strategis posisinya karena berada di kanan dan kiri jalan utama negara yang menyambungkan Indonesia dan Timor Leste.

\section{Karakteristik Pariwisata Berbasis Masyarakat di Desa Tulakadi}

Pariwisata berbasis masyarakat sejatinya adalah pengelolaan yang mengutamakan peran dan partisipasi masyarakat dalam pembangunan kepariwisataan (Dewi, 2013 dalam Nugraha, 2020). Desa Tulakadi sudah menunjukkan bahwa kepariwisataan di kawasan ini telah menitikberatkan peran serta masyarakat dalam kepemilikan dan pembangunannya. Adapun permasalahan mengenai jumlah kunjungan yang masih minim terjadi karena belum adanya pemetaan potensi daya tarik berdasarkan alam, budaya dan buatan. Pemetaan potensi daya tarik tidak akan bisa dilakukan dengan lancar bila tidak ada sumber daya manusia yang mengelolanya. Sumber daya manusia yang paling mudah ditemukan adalah masyarakat lokal yang menduduki wilayah tersebut. Berdasarkan hal tersebut, berikut terlampir 
data jumlah penduduk desa Tulakadi pembangunan pariwisata berbasis berdasarkan dusun dan kaitannya dengan masyarakat.

Tabel 1. Karakteristik Penduduk Desa Tulakadi Berdasarkan Jenis Kelamin

\begin{tabular}{ccccc}
\hline No & Nama Dusun & Laki-Laki & Perempuan & Total \\
\hline $\mathbf{1}$ & Dubanas & 174 & 163 & 337 \\
\hline $\mathbf{2}$ & Suliren & 108 & 116 & 224 \\
\hline $\mathbf{3}$ & Mudafehan & 172 & 149 & 321 \\
\hline $\mathbf{4}$ & Rairiti & 108 & 114 & 222 \\
\hline & TOTAL & 562 & 542 & 1104 \\
\cline { 2 - 5 } & & $51 \%$ & $49 \%$ & $100 \%$ \\
\hline
\end{tabular}

Sumber: olahan data sekunder Desa Tulakadi 2020

Total penduduk Desa Tulakadi berjumlah 1.104 jiwa, yang terbagi 51\% penduduk pria dan $49 \%$ penduduk wanita. Pemerintah desa memiliki kekuatan sumber daya manusia yang dapat dimanfaatkan untuk pembangunan kepariwisataan. Hal ini sudah ditunjukkan dalam berbagai kegiatan seperti Jumat Bersih, pengelolaan daya tarik asam Jokowi yang melibatkan pemuda pria, dan pembentukan kelompok perempuan yang memiliki agenda untuk melestarikan tenun ikat NTT. Dukungan seluruh penduduk desa adalah upaya yang harus dimaksimalkan, terutama untuk mencapai tujuan menjadi destinasi wisata di kawasan perbatasan yang berbasis masyarakat. Selanjutnya adalah data penduduk berdasarkan umur.

Tabel 2. Karakteristik Penduduk Desa Tulakadi Berdasarkan Umur

\begin{tabular}{llllllllll}
\hline No. & Nama Dusun & $\mathbf{0 - 1 2}$ & $\mathbf{1 3 - 2 4}$ & $\mathbf{2 5 - 3 6}$ & $\mathbf{3 7 - 4 8}$ & $\mathbf{4 9 - 6 0}$ & $\mathbf{6 1}$ keatas & Total \\
\hline $\mathbf{1}$ & Dubanas & 74 & 68 & 66 & 52 & 35 & 42 & 337 \\
\hline $\mathbf{2}$ & Suliren & 52 & 48 & 39 & 37 & 32 & 16 & 224 \\
\hline $\mathbf{3}$ & Mudafehan & 79 & 75 & 70 & 32 & 40 & 25 & 321 \\
\hline $\mathbf{4}$ & Rairiti & 48 & 48 & 45 & 43 & 23 & 15 & 222 \\
\hline & TOTAL & 253 & 239 & 220 & 164 & 130 & 98 & 1104 \\
\cline { 2 - 8 } & & $23 \%$ & $21 \%$ & $20 \%$ & $15 \%$ & $12 \%$ & $9 \%$ & $100 \%$ \\
\hline
\end{tabular}

Sumber: olahan data sekunder Desa Tulakadi 2020

Berdasarkan data dari WHO, usia produktif merupakan penduduk yang berusia mulai dari 13 tahun sampai dengan 48 tahun. Bila mengacu pada data lapangan, maka Desa Tulakadi berjumlah $56 \%$ atau jumlah mayoritas berada pada usia produktif. Peluang umur ini menunjukkan bahwa Desa Tulakadi memiliki peluang untuk melakukan pengelolaan pariwisata oleh masyarakat setempat. Masyarakat setempat dapat diikut sertakan dalam berbagai rangkaian kegiatan pariwisata baik yang dibuat oleh internal desa maupun bantuan dari pihak lain dalam bentuk sosialisasi, pelatihan, atau pekerjaan umum. Selanjutnya adalah potensi penerapan pariwisata berbasis masyarakat berdasarkan karakteristik tingkat Pendidikan.

Tabel 3. Karakteristik Penduduk Desa Tulakadi Berdasarkan Tingkat Pendidikan

\begin{tabular}{ccccccccc}
\hline Nc & Nama Dusun & $\begin{array}{c}\text { Belum/Tidak } \\
\text { Sekolah }\end{array}$ & PAUL & SD & SMI & SMA & S-1 & Total \\
\hline $\mathbf{1}$ & Dubanas & 103 & 21 & 105 & 29 & 64 & 15 & 337 \\
\hline $\mathbf{2}$ & Suliren & 90 & 3 & 93 & 17 & 15 & 6 & 224 \\
\hline $\mathbf{3}$ & Mudafehan & 122 & 21 & 151 & 18 & 9 & 0 & 321 \\
\hline $\mathbf{4}$ & Rairiti & 40 & 6 & 92 & 26 & 50 & 8 & 222 \\
\hline & TOTAL & 355 & 51 & 441 & 90 & 138 & 29 & 1104 \\
\cline { 2 - 8 } & & $32 \%$ & $4.6 \%$ & $40 \%$ & $8.1 \%$ & $12.5 \%$ & $2.8 \%$ & $100 \%$ \\
\hline
\end{tabular}

Sumber: olahan data sekunder Desa Tulakadi 2020 
Berdasarkan data tingkat Pendidikan, daya manusia yang potensial. Meningkatkan mayoritas penduduk mengenyam Pendidikan potensi sumber daya manusia ini bisa Sekolah Dasar ataupun Belum/ Tidak dilakukan dengan memberikan berbagai Sekolah. Hal ini menunjukkan tingkat pengetahuan seperti sosialisasi sapta pesona, pendidikan yang rendah. Tingkat Pendidikan sadar wisata, dan mengenai komponen yang rendah bukan berarti bahwa masyarakat kepariwisataan pada umumnya seperti yang tidak memiliki peluang dalam kegiatan telah dilakukan pihak akademisi dan kepariwisataan. Justru disini terdapat pemerintah daerah selama ini. Selanjutnya keuntungan bahwasanya pihak lain dalam adalah karakteristik masyarakat setempat pentahelix pariwisata dapat memiliki sumber berdasarkan pekerjaan.

Tabel 4. Karakteristik Penduduk Desa Tulakadi Berdasarkan Pekerjaan

\begin{tabular}{|c|c|c|c|c|c|c|c|c|c|}
\hline No. & $\begin{array}{l}\text { Nama } \\
\text { Dusun }\end{array}$ & $\begin{array}{l}\text { Belum/ } \\
\text { Tidak Bekı }\end{array}$ & Petani & Peternak & $\begin{array}{l}\text { Pedagang } \\
\text { UMKM }\end{array}$ & PNS & Buruh & Wirausaha & Total \\
\hline 1 & Dubanas & 93 & 162 & 16 & 13 & 3 & 33 & 17 & 337 \\
\hline 2 & Suliren & 76 & 118 & 2 & 7 & 2 & 18 & 1 & 224 \\
\hline 3 & Mudafehan & 93 & 168 & 0 & 3 & 1 & 51 & 5 & 321 \\
\hline \multirow[t]{3}{*}{4} & Rairiti & 44 & 127 & 0 & 3 & 6 & 37 & 5 & 222 \\
\hline & TOTAL & 306 & 575 & 18 & 26 & 12 & 139 & 28 & 1104 \\
\hline & & $28 \%$ & $52 \%$ & $1.6 \%$ & $2.7 \%$ & $1.2 \%$ & $12 \%$ & $2.5 \%$ & $100 \%$ \\
\hline
\end{tabular}

Sumber: olahan data sekunder Desa Tulakadi 2020

Berdasarkan hasil pengumpulan data sekunder, sebanyak $28 \%$ masyarakat setempat Belum/Tidak bekerja. Masyarakat dalam klasifikasi ini termasuk juga pensiunan dan veteran, namun jumlahnya tidak banyak, hanya sekitar $8 \%$ nya saja sehingga sebanyak $20 \%$ nya adalah usia produktif. Bila dilihat dari segi positif, tentu $20 \%$ sumber daya manusia yang masuk dalam klasifikasi belum atau tidak bekerja dapat dialihkan untuk mengikuti sertifikasi kompetensi kepariwisataan. Tujuannya adalah untuk memudahkan masyarakat mendapatkan pekerjaan terutama dalam bidang kepariwisataan. Pekerjaan utama warga setempat adalah petani, sebanyak $52 \%$, terlihat dari banyaknya pematang sawah yang terhampar disebelah kiri dan kanan jalan negara perbatasan Indonesia dan Timor Leste. Karakteristik masyarakat setempat menunjukkan bahwa potensi pariwisata berbasis masyarakat ada peluang untuk dikembangkan dengan bantuan berbagai pihak seperti akademisi dan pihak pemerintah. Tujuannya adalah untuk menghidupkan kegiatan pariwisata di kawasan perbatasan Desa Tulakadi.

Karakteristik masyarakat Desa Tulakadi didukung oleh kepala desa yang sangat menerapkan keharmonisan dan kedamaian dalam memimpin Desa Tulakadi. Kepala Desa selalu mendukung kegiatan positif yang dilakukan masyarakat setempat. Salah satunya yang baru dimulai adalah mengenai keterbukaan terhadap kepariwisataan. Sejak tahun 2018, keterbukaan itu muncul ditandai dengan mulai penataan wilayah dan pembentukan kelompok-kelompok masyarakat berdasarkan subjek pengembangan yakni: kelompok perempuan, kelompok tenun, kelompok petani, dan kelompok perbengkelan. Selain itu, etos kerja yang tinggi dilakukan pemerintah desa sehingga pada setiap kegiatan yang dilakukan, seluruh warga kompak mengikuti kegiatan tersebut. Konsensus yang harmonis dan kesepakatan antara pemerintah dan masyarakat membuat kehidupan bermasyarakat di Desa Tulakadi terlihat harmonis. Salah satu kegiatan Bersama di desa Tulakadi adalah Jum'at bersih. Seluruh warga desa baik tua ataupun muda wajib berpartisipasi, terdapat absensi yang memantau jalannya kegiatan Jumat Bersih. Masyarakat membawa alat kebersihan yang dimiliki dari rumahnya, kemudian menyebar di areal perbatasan Desa Tulakadi. Kegiatan ini memberikan dampak positif bagi penguatan sosial dan kebersihan areal Desa 
Tulakadi yang sekarang mulai berfungsi sebagai destinasi wisata.

Karakteristik pariwisata berbasis masyarakat juga semakin terlihat ketika pengelolaan destinasi wisata dilakukan Bersama-sama dan swadaya. Sampai pada akhirnya Desa Tulakadi mendapatkan penghargaan sebagai desa inovasi dan prakarsa yang diberikan oleh Kementerian

Desa di tahun 2019.Penghargaan tersebut diberikan untuk nominasi desa terbaik nasional kategori prakarsa inovasi desa tahun 2018 dan dari Pemerintah Belu sebagai desa terbaik kategori prakarsa dan inovatif tingkat Provinsi NTT tahun 2018. Penghargaan ini merupakan titik balik masyarakat desa Tulakadi yang mulai semangat dan terbuka dengan kegiatan kepariwisataan. Tidak lama setelah penghargaan ini, wisatawan semakin banyak berkunjung ke destinasi-destinasi yang ada di Desa Tulakadi. Masyarakat belum banyak mendapatkan manfaat ekonomi dari fenomena tersebut, namun kegiatan pariwisata sudah dilakukan dengan menggunakan prinsip pariwisata berbasis masyarakat. Dimana wisatawan datang berkunjung menikmati kegiatan pariwisata dan bersenang-senang dengan keterlibatan hasil pengelolaan dan penataan yang dilakukan oleh masyarakat setempat.

\section{Pengembangan Pariwisata Berbasis Masyarakat Berdasarkan Analisis Potensi Wisata Desa Tulakadi}

Pengembangan Pariwisata Berbasis masyarakat Desa Tulakadi dianalisis berdasarkan pendekatan kunci menurut (Pitayasa, 2011). Hal ini mengacu pada temuan-temuan lapangan dan fakta karakteristik yang dimiliki oleh masyarakat Desa Tulakadi. Kunci pembangunan pariwisata berbasis masyarakat ini meliputi enam indicator yang akan dipaparkan dalam bagian ini.

(1) Adanya dukungan pemerintah; Desa Tulakadi telah mendapatkan dukungan dari beberapa instansi baik pusat maupun daerah. Seperti pada tahun 2018, Kementerian Pariwisata berkunjung untuk melakukan peninjauan potensi daya tarik wisata sekaligus cikal bakal bergeliatnya pembangunan pariwisata kerakyatan di kawasan perbatasan Desa Tulakadi.Menteri pariwisata memberikan dukungan serta semangat untuk warga setempat untuk membangun potensi pariwisata yang ada di kawasan perbatasan Desa Tulakadi.Lebih dari itu, Kementerian Desa juga memberikan dukungan dengan menominasikan Desa Tulakadi sebagai kandidat desa terbaik tingkat nasional dalam bidang prakarsa dan inovasi desa. Dua pencapaian ini merupakan tahapan awal masyarakat mulai memiliki pandangan terbuka terhadap kepariwisataan. Selain dua kementerian pusat yang datang mendukung, pemerintah daerah melalui Dinas Pariwisata Kabupaten Belu dan Pemerintah Desa Tulakadi juga turut serta dalam memberikan penguatan dalam mengembangkan pariwisata berbasis masyarakat di Desa Tulakadi. Adapun kegiatan yang dilakukan oleh Dinas Pariwisata Belu adalah dengan memberikan sosialisasi dan pelatihan-pelatihan sadar wisata bagi masyarakat setempat.

(2) Partisipasi dari stakeholder; Menurut Menteri Pariwisata Arif Yahya, 2018, stakeholder dalam kepariwisataan dapat dipahami dalam model pentahelix pariwisata. Terdapat lima unsur pentahelix dalam rangka mencapai target pembangunan pariwisata. Pertama adalah partisipasi akademisi dalam pembangunan pariwisata berbasis masyarakat Desa Tulakadi. Sejauh ini, perguruan tinggi negeri di Provisi Nusa Tenggara Timur telah memberikan berbagai sosialisasi dan pelatihan untuk meningkatkan kesadaran masyarakat lokal. Salah satunya berasal dari jurusan pariwisata Politeknik Negeri Kupang yang memberikan sosialisasi mengenai sadar wisata, sapta pesona, dan pengelolaan homestay. Kegiatan ini dilaksanakan dalam rangka membangun desa wisata di Desa Tulakadi. Sumbangan pihak akademisi dalam pembangunan pariwisata berbasis masyarakat di Desa Tulakadi berdampak pada pemahaman masyarakat yang meningkat dalam mengelola pariwisata berdasarkan 7 prinsip dasar sapta pesona (aman, tertib, bersih, sejuk, indah, ramah tamah, dan kenangan). Selain itu, akademisi dapat menjadi mediator yang mendukung pembentukan kelompok sadar 
wisata desa tulakadi, dan homestay yang berasal dari rumah masyarakat setempat untuk tempat singgah wisatawan.

Stakeholder kedua adalah komunitas. Partisipasi komunitas yang terlihat pada pengelolaan pariwisata di Desa Tulakadi masih berupa embrio atau inisiasi. Inisiasi awal ini dilakukan oleh pemerintah desa melalui kepala desa yang membentuk empat kelompok masyarakat dalam berbagai bidang. Pertama kelompok perempuan, kedua kelompok tani, ketiga kelompok pemuda dan kelompok perbengkelan. Setiap kelompok memiliki tugas dan kegiatannya masing-masing. Melalui adanya kelompok komunitas ini, maka pengelolaan pariwisata lebih mudah, tidak harus dimulai sejak awal. Namun disini, partisipasi dalam kegiatan pariwisata masih belum terlihat. Partisipasi ketiga yakni berasal dari pemerintah. Seperti dijelaskan pada alinea sebelumnya, peran pemerintah dalam pembangunan pariwisata di Desa Tulakadi sangat serius. Hal ini diperlihatkan dari komitmen kepala desa untuk menjadikan Desa Tulakadi sebagai salah satu destinasi yang berbasis masyarakat dalam bentu desa wisata. Selain itu, atas kerja keras kepala desa dan masyarakat setempat, Desa Tulakadi mendapatkan penghargaan sebagai Desa dengan Inovasi terbaik oleh Kementerian Desa. Selanjutnya media, sejauh ini, media merupakan alat yang paling ampuh dalam meningkatkan kunjungan wisatawan ke destinasi wisata. Desa Tulakadi telah memiliki akun Instagram resmi yang dikelola oleh masyarakat setempat yang dapat mengoperasikannya. Anggota masyarakat tersebut adalah salah satu anggota kelompok sadar wisata yang dibentuk hasil sosialisasi oleh akademisi. Sehingga media yang sejauh ini dikembangkan belum berdampak optimal. Namun, hal ini adalah inisiasi yang baik karena kedepan terdapat peluang Desa Tulakadi dikenal dengan adanya akun Instagram dan hashtag \#DesaTulakadi yang mulai digaungkan oleh pengunjung maupun wisatawan. Partisipasi yang masih sangat minim adalah dari pihak industri, yang merupakan bagian tour operator, penyediaan paket wisata, dan investasi amenitas untuk penunjang kegiatan wisata. Nama Desa Tulakadi yang baru mulai terdengar membuat investor masih enggan untuk berpartisipasi.

(3) Pembagian keuntungan yang adil; sampai sejauh ini, tahapan pengembangan pariwisata di Desa Tulakadi belum memberikan keuntungan optimal bagi masyarakat setempat. Keuntungan masih didapatkan bagi mereka yang memiliki usaha kerajinan stempat seperti usaha anyaman lontar, usaha makanan, dan usaha penjualan tenun menggunakan pewarna alami.

(4) Penggunaan sumber daya lokal secara berkesinambungan; Kekayaan Desa Tulakadi dalam sumber daya alam berbentuk hasil bumi yang berupa jambu tanpa biji, jagung, buah asam, dan jamur tiram. Tidak hanya itu, pematang sawah yang membentang di sepanjang jalan dari Desa Tulakadi menuju PLBN Mota'ain menandakan bahwa Desa Tulakadi juga wilayah penghasil padi di perbatasan. Selain komoditas tersebut, sumber daya lokal lain adalah dalam bentuk budaya yang terlihat dari hasil pengolahan kain tenun oleh mama-mama setempat, olahan kerajinan dari daun lontar yang dibentuk menjadi asbak dan kerajinan kreatif lainnya, juga makanan khas setempat seperti jagung bose (jagung yang diberi kuah).

(5) Penguatan institusi lokal; Institusi lokal yang ada di Desa Tulakadi berupa kelompokkelompok dan komunitas yang Bersama-sama menekuni satu bidang untuk meningkatkan kesejahteraan masyarakat. Kelompok tersebut adalah kelompok perempuan, kelompok tani, kelompok pemuda, dan kelompok perbengkelan. Penguatan institusi lokal dalam bentuk kelompok komunitas ini selalu dikuatkan dengan berbagai kegiatan kemasyarakatan seperti kerja bakti setiap hari Jum'at. Selain itu, mengikutsertakan perwakilan dari setiap kelompok secara bergilir dalam mengikuti sosialisasi yang dilaksanakan oleh pemerintah maupun akademisi di Desa Tulakadi. Sehingga dalam hal ini penguatan institusi walaupun masih sederhana, tapi mulai diterapkan oleh Desa Tulakadi.

(6) Keterkaitan antara level regional dan nasional; keberadaan Desa Tulakadi yang strategis merupakan kekuatan yang menjadikan 
lokasi ini sering dilewati calon wisatawan. Wisatawan yang datang biasanya berasal dari Negara Timor Leste sehingga pada bagian ini, Desa Tulakadi memiliki paparan level regional. Berdasarkan temuan lapangan dalam penelitian ini, potensi pariwisata di Desa Tulakadi memiliki jenis yang berbeda. Pertama adalah pariwisata berbasis sumber daya alam yakni persawahan, pegunungan dan perbukitan, juga pemandangan laut.
Kedua adalah pariwisata berbasis budaya, yakni tarian likurai, makanan khas jagung bose, kain tenun khas buatan perempuan setempat, dan kebiasaan masyarakat mengunyah sirih pinang. Ketiga adalah wisata buatan yang menjadi daya tarik penguat yakni destinasi Asam Jokowi yang memiliki narasi-narasi perjuangan.

Tabel 5. Ringkasan Pengembangan Pariwisata Berbasis Masyarakat Berdasarkan Potensi dan Karakteristik Desa

\begin{tabular}{ll}
\hline No. & Variabel \\
\hline $\mathbf{1}$ & Adanya dukungan pemerintah
\end{tabular}
Tulakadi

\section{Kondisi}

1. Kementerian Pariwisata: memberikan stimulus melalui dukungan pemerintah desa dan kunjungan ke masyarakat Desa Tulakadi

2. Kementerian Desa: memberikan penghargaan dan bantuan kepada Desa Tulakadi sebagai desa prakarsa inovasi nasional 3. Pemerintah Daerah melalui Dinas Pariwisata Belu: memberikan pelatihan sadar wisata bagi masyarakat

4. Pemerintah Desa: memberikan dukungan dan stimulus melalui kerja bakti, musyawarah, dan pembentukan kelompokkelompok masyarakat.

\begin{tabular}{|c|c|c|}
\hline 2 & Partisipasi dari stakeholder & $\begin{array}{l}\text { Akademisi: memberikan sosialisasi sapta pesona dan pelatihan } \\
\text { olahan makanan ringan berbahan asam, membentuk kelompok } \\
\text { sadar wisata dengan persetujuan pemerintah desa Tulakadi }\end{array}$ \\
\hline 3 & Pembagian keuntungan yang adil & $\begin{array}{l}\text { Pembagian keuntungan belum dirasakan optimal karena } \\
\text { kegiatan pariwisata yang belum berjalan dengan konsisten }\end{array}$ \\
\hline 4 & $\begin{array}{l}\text { Penggunaan sumber daya lokal secara } \\
\text { berkesinambungan }\end{array}$ & $\begin{array}{l}\text { Pemanfaatan sumber daya mulai dikembangkan dari hasil } \\
\text { bumi lokal seperti jagung, padi, jambu tanpa biji, buah asam, } \\
\text { dan jamur. Selain itu, sumber daya budaya lainnya seperti kain } \\
\text { tenun dan pewarna alaminya masih digunakan sebagai daya } \\
\text { tarik yang pengelolaannya masih terbatas. }\end{array}$ \\
\hline 5 & Penguatan institusi lokal & $\begin{array}{l}\text { Institusi lokal dikuatkan melalui pembentukan berbagai } \\
\text { kelompok masyarakat seperti kelompok perempuan, kelompok } \\
\text { tenun, kelompok tani, dan kelompok perbengkelan. }\end{array}$ \\
\hline 6 & $\begin{array}{l}\text { Keterkaitan antara level regional dan } \\
\text { nasional }\end{array}$ & $\begin{array}{l}\text { Faktor kedekatan dengan Negara Timor Leste membuat daya } \\
\text { tarik Desa Tulakadi di kawasan perbatasan Indonesia memiliki } \\
\text { potensi kerjasama dibidang regional. Mengingat wisatawan } \\
\text { yang datang berasal dari mancanegara. }\end{array}$ \\
\hline
\end{tabular}

Sumber: Data Primer, (2020)

Potensi pariwisata yang cukup bervariasi ini memerlukan sebuah upaya pengembangan yang menggunakan pendekatan komunitas. Oleh karena itu, upaya pengembangan pariwisata berbasis masyarakat di Desa Tulakadi sejauh ini telah berjalan memasuki tahap pelaksanaan. Hal ini ditandai dengan dukungan dan partisipasi dari pentahelix kepariwisataan yang memberikan sosialisasi dan pelatihan bagi masyarakat Desa Tulakadi. Selain itu, pariwisata berbasis masyarakat merupakan pendekatan yang paling cocok dilaksanakan di Desa Tulakadi didasarkan atas temuan temuan berikut: sudah terbentuknya kelompok masyarakat yang memudahkan pengelolaan kepariwisataan di Desa Tulakadi, dibentuknya kelompok sadar wisata saat sosialisasi oleh akademisi, dan penghargaan yang diperoleh atas hasil kerjasama seluruh masyarakat Desa Tulakadi. Kekuatan masyarakat Desa Tulakadi merupakan sebuah modal yang dapat dijadikan sebagai kekuatan untuk mengelola Desa Tulakadi sebagai salah satu destinasi 
wisata yang memiliki daya tarik tersendiri di kawasan perbatasan.

\section{SIMPULAN}

Potensi daya tarik wisata Desa Tulakadi terbagi menjadi tiga yakni daya tarik alam yang berupa perbukitan, persawahan, dan pemandangan laut. Kedua yakni daya tarik budaya yang terdiri dari tarian Likurai sebagai ucap syukur panen dan tarian sambutan, olahan makanan khas jagung bose, anyaman lontar, dan juga kain tenun. Ketiga adalah daya tarik wisata buatan di kawasan bukit Asam Jokowi. Daya tarik wisata buatan inilah yang menjadi symbol karakteristik penerapan pendekatan pariwisata yang berbasis masyarakat di Desa Tulakadi. Selain potensi yang dipaparkan dalam penelitian ini, masih banyak daya tarik lain yang belum dieksplorasi lebih mendalam. Hal ini masih membutuhkan kerjasama dari berbagai pihak secara stimultan untuk menghasilkan destinasi wisata perbatasan yang diminati oleh wisatawan.

Karakteristik pariwisata berbasis masyarakat tercermin dari data kependudukan warga desa Tulakadi yang sebagian besar adalah Pria sebanyak $51 \%$ yang bertugas sejauh ini untuk mengelola dan mempersiapkan daya tarik buatan agar menarik bagi wisatawan dan $49 \%$ wanita yang mengelola daya tarik budaya melalui kelompok perempuan dalam membuat tenun dan mengolah jagung bose. Potensi lain dalam pariwisata berbasis masyarakat ditunjukkan dari jumlah penduduk yang memasuki usia produktif berjumlah $56 \%$ yang berarti bahwa masyarakat sebenarnya siap untuk mengelola daya tarik wisata berdasarkan potensi yang ada. Diperlukan kerjasama yang nyata dari pentahelix pariwisata dalam mewujudkan target ini.

Pengembangan pariwisata berbasis masyarakat berdasarkan analisis potensi dan karakteristik desa terangkum pada 5 agenda besar yakni dukungan pemerintah yang terdiri dari pemerintah pusat, daerah, dan desa, partisipasi stakeholder seperti akademisi dari jurusan pariwisata untuk membuka wawasan masyarakat, pembagian keuntungan yang adil bagi masyarakat yang berpartisipasi dalam pariwisata, penguatan SDM dan institusi lokal melalui usaha sosialisasi sadar wisata dan sapta pesona, serta pelatihan pengelolaan desa wisata.

\section{UCAPAN TERIMA KASIH}

Penulis mengucapkan terima kasih kepada Pemerintah Desa Tulakadi dan Dinas Pariwisata Kabupaten Belu, serta Kementerian Ristek BRIN melalui kesempatan penelitian melalui skema Penelitian Dosen Pemula. Sekaligus juga jurusan pariwisata Politeknik Negeri Kupang yang telah melakukan upaya pendampingan desa wisata kepada masyarakat di Desa Tulakadi dan membantu terselesaikannya penelitian ini.

\section{REFERENSI}

Asker, S., Boronyak, L., Carrard, N., and Paddon, M., (2010). Effective Community Based Tourism, A Best Practice Manual. Singapore: Sustainable Tourism Cooperative Research.

Dewi, M. H. (2013). Pengembangan Desa Wisata Berbasis Partisipasi Masyarakat Lokal di Desa Wisata Jatiluwih Tabanan Bali. Kawistara UGM, Vol 3.

Ernawati, N. M., Dowling, R., \& Sanders, D. (2015). Tourists' perceptions of community-based tourism products for sustainable tourism in Bali, Indonesia. In The Practice of Sustainable Tourism (pp. 117-134). Routledge.

Hausler, N., Strasdas, W. (2003). Training Manual For Community-based Tourism, Zschortau: Inwent.

Maulana, A. 2019. Pemetaan Proskep Pasar Wisatawan Nusantara di Indonesia. 
Jurnal Kepariwisataan Indonesia, Vol. 13, Vol. 1, p 1-15.

Nugraha, Y. E., Kesos, S., \& Par, M. (2020, June). Pengembangan Wisata Bahari Pantai Mulut Seribu Sebagai Daya Tarik Wisata Berkelanjutan Di Kabupaten Rote, Nusa Tenggara Timur. In Journey (Journal of Tourismpreneurship, Culinary, Hospitality, Convention and Event Management) (Vol. 2, No. 2, pp. 2546).

O. Nyumba, T., Wilson, K., Derrick, C. J., \& Mukherjee, N. (2018). The use of focus group discussion methodology: Insights from two decades of application in conservation. Methods in Ecology and evolution, 9(1), 20-32.

Pantiyasa, I. W. (2011). Pengembangan Pariwisata Berbasis Masyarakat (Community Based Tourism) dalam Pemberdayaan Masyarakat: Studi Kasus Di Desa Bedulu, Blah Batuh, Gianyar. Jurnal Ilmiah Hospitality Management, Vol 1 No 2.

Sugiyono, P. D. (2015). Metode penelitian dan pengembangan. Res. Dev. D, 2015, 39-41.

Sunarjaya, I. G., Par, S., Par, M., Nugraha, Y. E., Kesos, S., \& Par, M. (2019, March). Analisis Persepsi Employee Empowerment Terhadap Employee Turnover Intention Di Dewi Sinta Hotel. In Journey (Journal of Tourismpreneurship, Culinary, Hospitality, Convention and Event Management) (Vol. 1, No. 1, pp. 182206).

Tasci, Asli D.A., Semrad, Kelly J. and Yilmaz, Semih S., (2013, Community Based Tourism Finding The Equilibrium in COMCEC Context, Setting the Pathway for the Future.
Ankara: COMCEC Coordination Office. 